\title{
個人別エネルギー所要量算出図の作成について
}

\author{
大谷八峯 \\ 厚生省児童家庭局 母子衛生課

\section{Nomogram of Energy Allowance} \\ Yatsuho Ohtani \\ Maternal and Child Health Division \\ Ministry of Health and Welfare
}

昭和 54 年 8 月に公衆衛生審議会から厚生大臣に「日本人の栄養所要量等について」が答申 ${ }^{11}$ され, 昭和55年 4 月から使用されることになった2。

今回の答申では, 体重 $\mathrm{kg}$ 当たり又は, エネルギー $1,000 \mathrm{kcal}$ 当たり等でも栄養所要量が示されて打り, 個人を対象としても利用できるよう配虑されている。

エネルギー所要量についても体重 $\mathrm{kg}$ 当たりで示されているが，これは推計基準体重をもとに算定されてい るため, 推計基準体重からずれている者には適用できず，適当な補正を行う必要があり，いくつかの補正方法 が示されている1)。しかし，ぞの補正方法もかなり煩雑な計算が伴う。そこで補正方法の1つでもあり又，昭 和44年に設定され今回な和準拠されている体表面積当たり基礎代謝量の性別，年齢別基準值 ${ }^{3}\left(\mathrm{kcal} / \mathrm{m}^{2} / \mathrm{hr}\right.$. を用いて，モモクラフィーによるェネルギー所要量算出図を作成したので紹介する。

\section{ノモグラムの作成}

エネルギー所要量は, 次の式により算出される。

$$
\mathrm{A}=\mathrm{B}+\mathrm{B} x+\frac{1}{10} \mathrm{~A}
$$

$\mathrm{A}: 1$ 日のエネルギー所要量

B：1日の基礎代謝量

$x:$ 生活活動指数

$\frac{1}{10} \mathrm{~A}:$ 食物摂取によるエネルギー代謝の增加量（特異動的作用）

なお今回のエネルギー所要量の基礎となる基礎代謝量は体重当たりで示されているが，これを個人に適用す る場合, 体重が推計基準体重と著しく異なる場合は補正する必要がある。55年改定日本人の栄養所要量では, いくつかの補正の方法を紹介している。ここでは個人の基礎代謝 1 日量を得る方法として 44 年まで用いられて いた体表面積を用いる方法をとった。

(1)式を変形すると

$$
\mathrm{A}=\frac{10}{9}(1+x) \mathrm{B}
$$

これを体表面積当たりの基碟代謝基準值を用いて変形すると 


$$
\mathrm{A}=\frac{10}{9}(1+x) \mathrm{B}^{\prime} \times 24 \times \mathrm{S}
$$

$\mathrm{B}^{\prime}$ : 体表面積当たり基礎代謝基準值 $\left(\mathrm{kcal} / \mathrm{m}^{2} / \mathrm{hr}\right.$.)

$24: 24$ 時間 ( 1 日)

$\mathrm{S}$ : 体表面積 $\left(\mathrm{m}^{2}\right)$

$1 \sim 5$ 歳: $\mathrm{S}=\mathrm{W}^{0.423} \times \mathrm{H}^{0.362} \times 381.89 \div 10,000$

6 藏以上: $\mathrm{S}=\mathrm{W}^{0.444} \times \mathrm{H}^{0.663} \times 88.83 \div 10,000$

$\mathrm{S}$ : 体表面積 $\left(\mathrm{m}^{2}\right)$

$\mathrm{W}$ : 体重 $(\mathrm{kg})$

$\mathrm{H}:$ 身長 $(\mathrm{cm})$

$\Gamma \frac{10}{9}(1+x) \mathrm{B}^{\prime} \times 24 」$ は, 性, 年齢, 労作強度によって定数となる。これを「K」で表わすと(3)式は

$\mathrm{A}=\mathrm{K} \times \mathrm{S}$

に変形できノモグラムを作成することができる。そこで体表面積を求めるノモグラムをつくり，これとの組合 せを試みた。

作成したノモグラムを図 1，2，3，4 亿示した。図 1 は，1～5 歳児の普通の労作用，図 2 は 6 ～15歳の 普通労作用, 図 3,4 は15歳以上の軽い労作, 普通の労作及びやや重い労作, 重い労作用をそれぞれ示してい る。

\section{ノモグラムの使用法}

1）該当する図を選ぶ。

2）該当する身長と体重を直線で結び, 体表面積の軸との交点を求める（その目盛を読めば，当該者の体表 面積 $\left(\mathrm{m}^{2}\right)$ である)。

3）体表面積の交点と, 性別年齡の目盛とを直線で結び, エネルギー所要量との交点を求める。

4) その交点の数值が, 求めようとする個人のエネルギー所要量である。

肥満者に対しては，本人の体重を使うよりも身長に応じた正常な体重域を用いるのが適当と考兄れる。

\section{ノモグラムの展開}

そこで，身長別標準体重表を用いれば，身長にみあった標準体重が決まるので，例光ば図 3 を用いて，それ ぞれの身長とそれにみあう標準体重を直線で結び, 体表面積の軸との交点を 1 づつ求め, その交点にその身 長の数值を目盛る。すると，その軸は身長の值で目盛られているが，その意味するところは，その身長とそれ にみあら標準体重とから計算される体表面積である。このようなことを行えば, 体表面積算出のためのノモグ ラムが省略できるので，もっと単純なノモグラムができあがることになる。

身長別標準体重については，種々の数值があるが，ここでは，我国でよく用いられている松木の標準体重 ${ }^{4)}$ を用いて身長に対する体重から体表面積を求めてノモグラムを作成した。それを参考として図 5 , 6 に示す。 他の身長別標準体重表を用いれば，又別のノモグラムが作成できることはいらまですない。身長で目盛ったの 

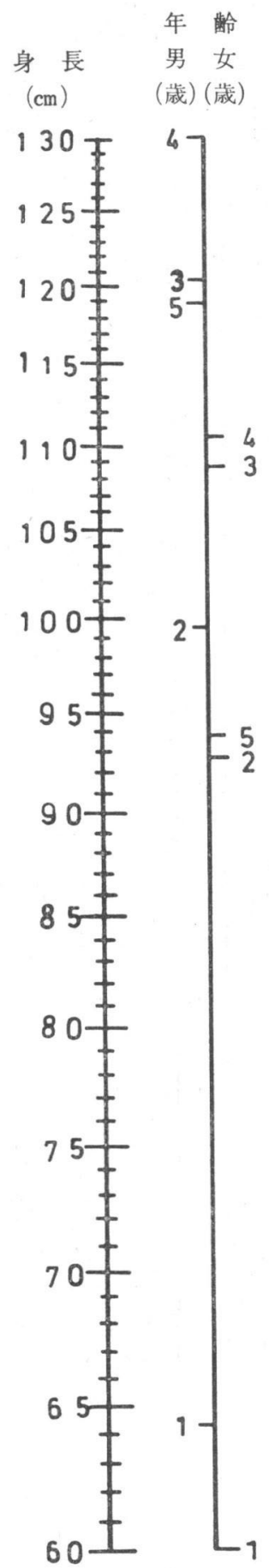

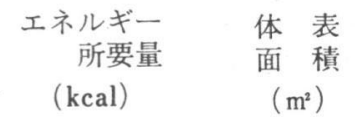

1900 美 $\mathrm{f} 0.85$
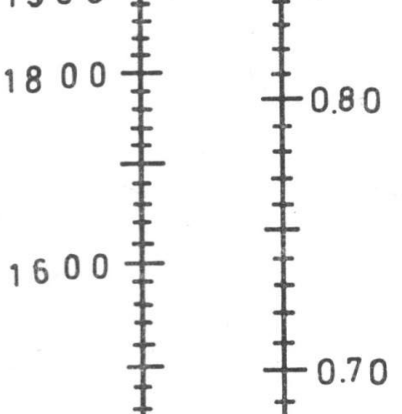

重

$(\mathrm{kg})$

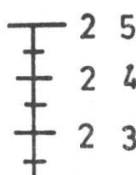

千22

$+21$

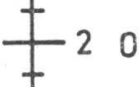

$+19$
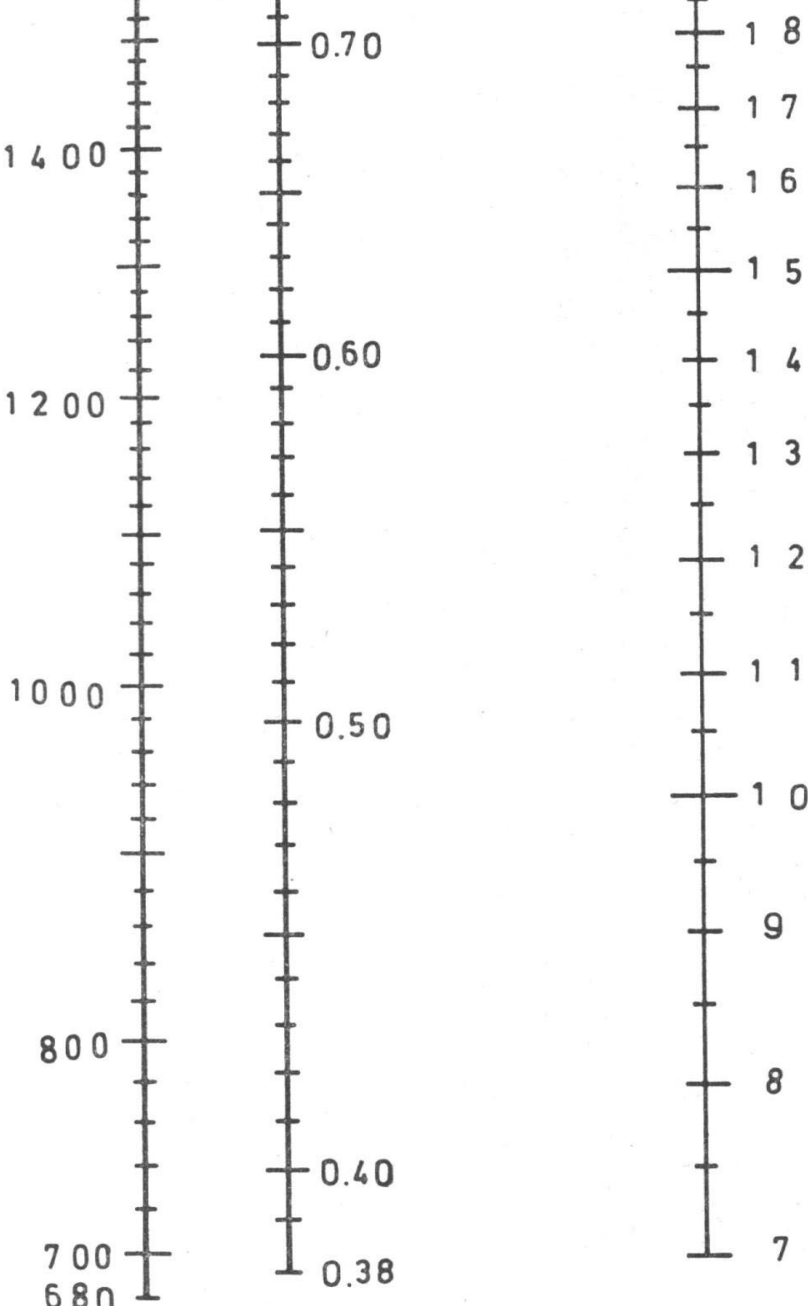

図 1 エネルギー所要量算出図（1～5 歳用）

は，身長にみあった体重にすることは可能であるが，体重にみあった身長にするこるは，不可能であるからで ある。 

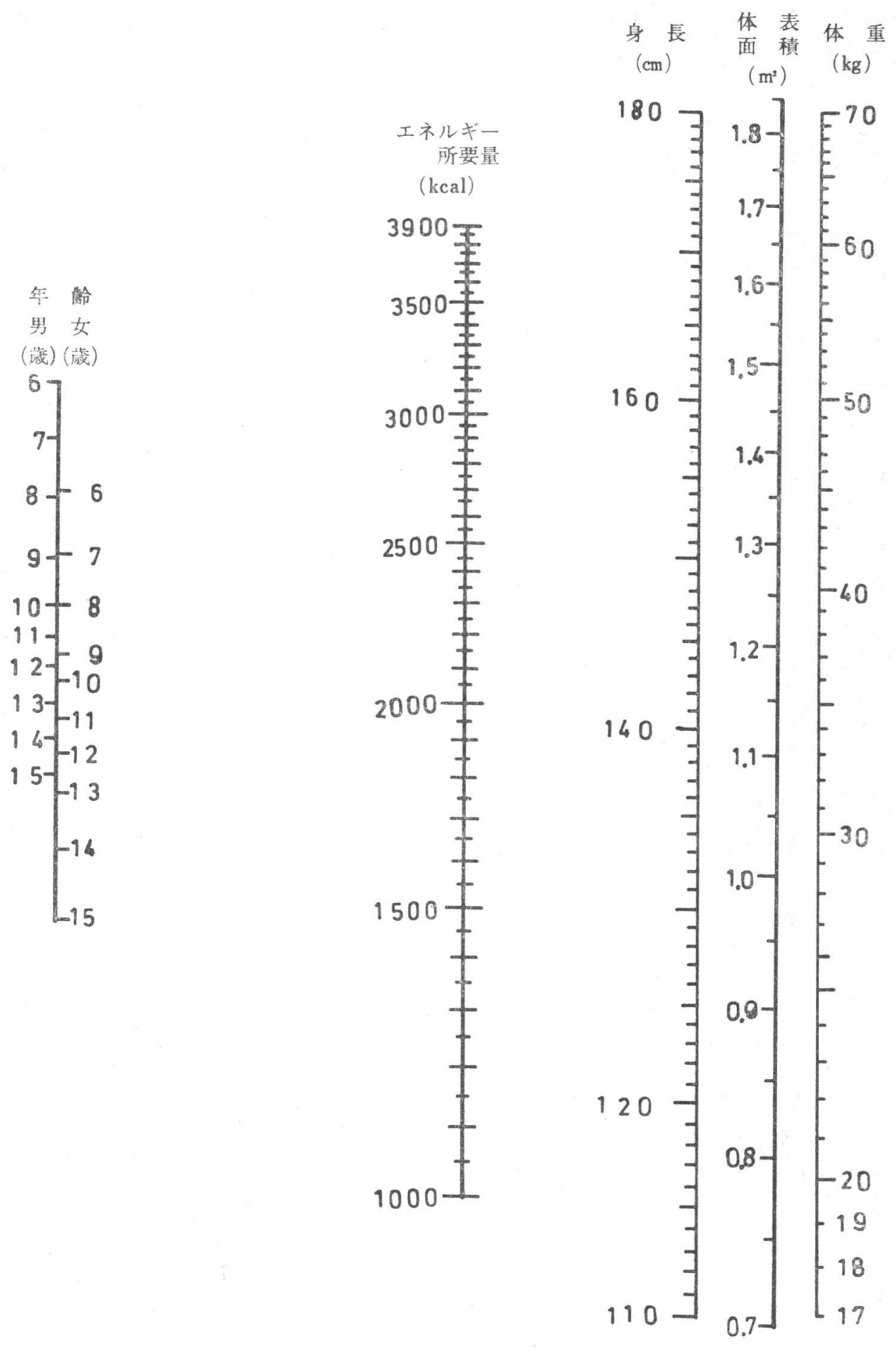

図 2 エネルギー所要量算出図（6１5歳用）

おわりに

今回報告したノモグラムは，見やすいこと使いやすいことを主眼として作成したつるりである。即ちこの図 表と定規があ机ば, 直ちにェネルギー所要量が算出できるので今後の個別栄盖指導において活用していただき 


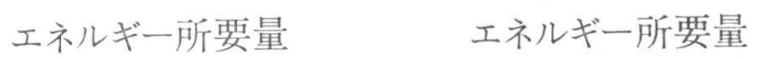

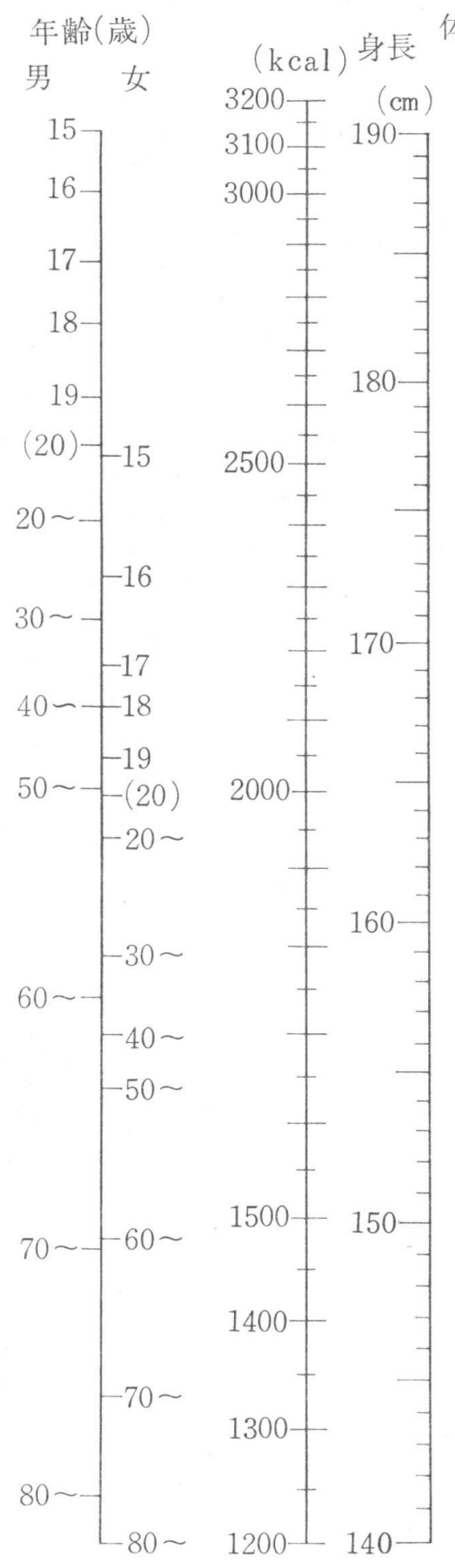

年齢(歳)
面積

軽い学作
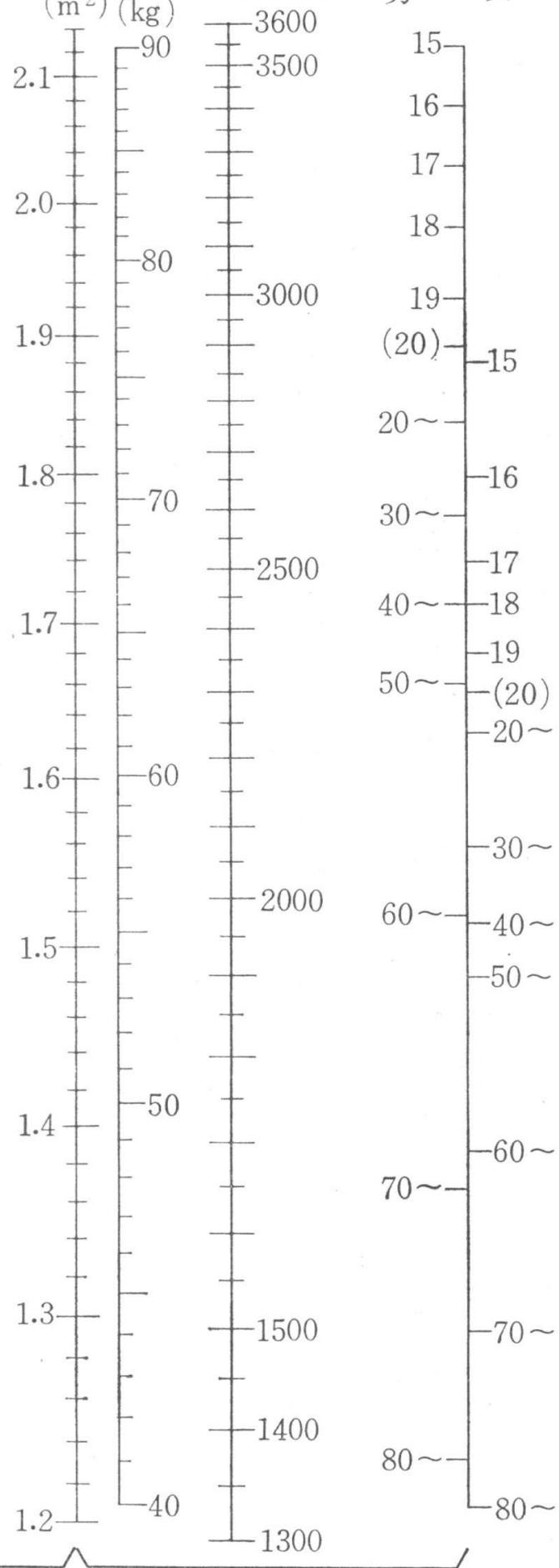

図 3 エネルギー所要量算出図 (15歳以上用) 


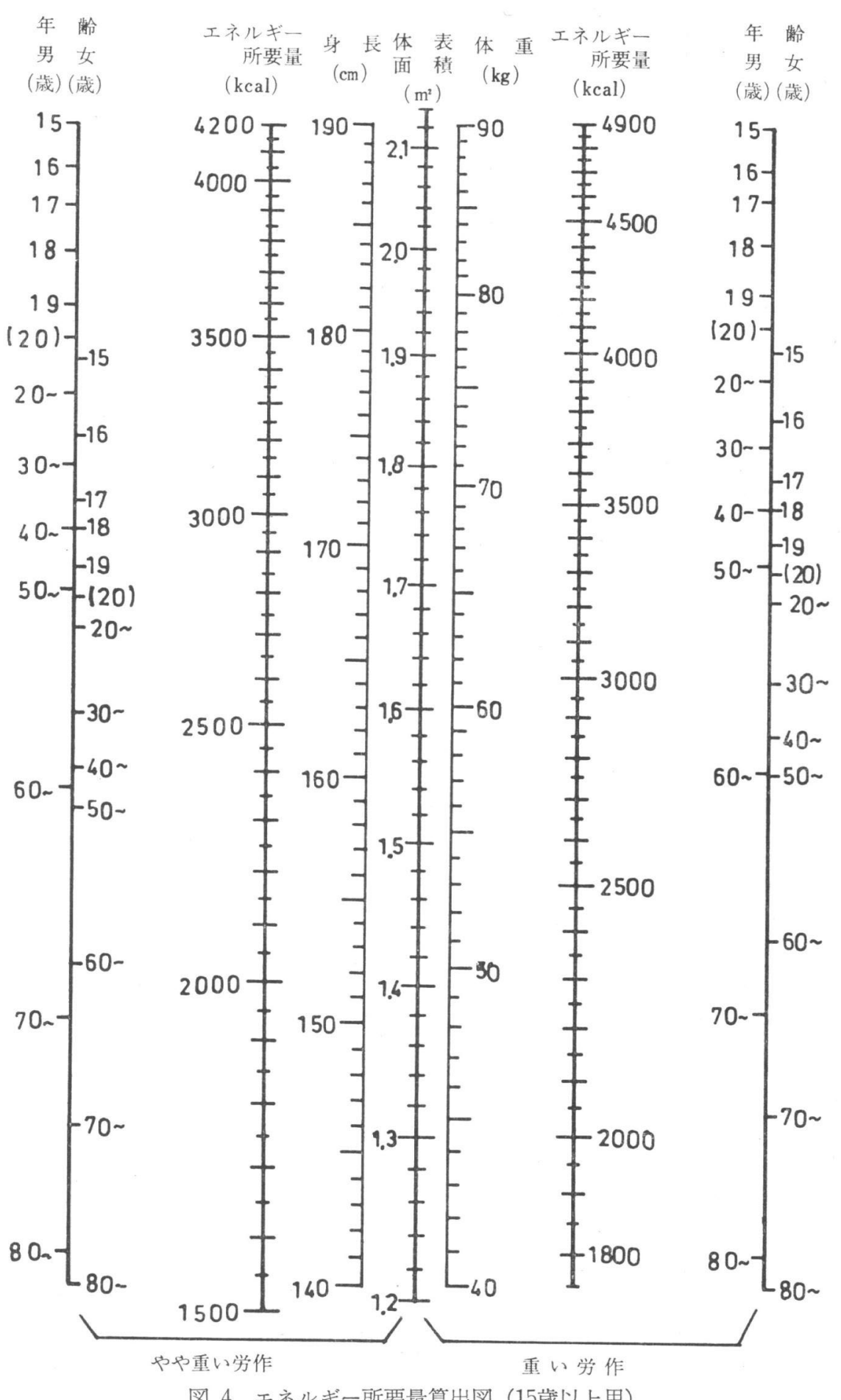

図 4 エネルギー所要量算出図 (15歳以上用)

たい。

なお，50年改定の時から個人にもつかえるょらにと体重当たりで示されてきたが，体表面積の計算のよらに ベキ乗計算がともなうため体重当たりで表現したふしもみられるが，推計基準体重からずれた時の補正のはん ざつさ及びこのよらなノモグラムの利用又は，プログラム電卓等の普及により計算のはんざつさはなくなった 


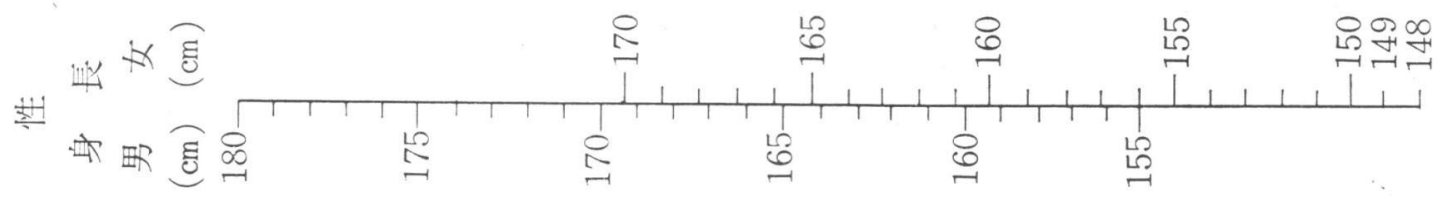

暗

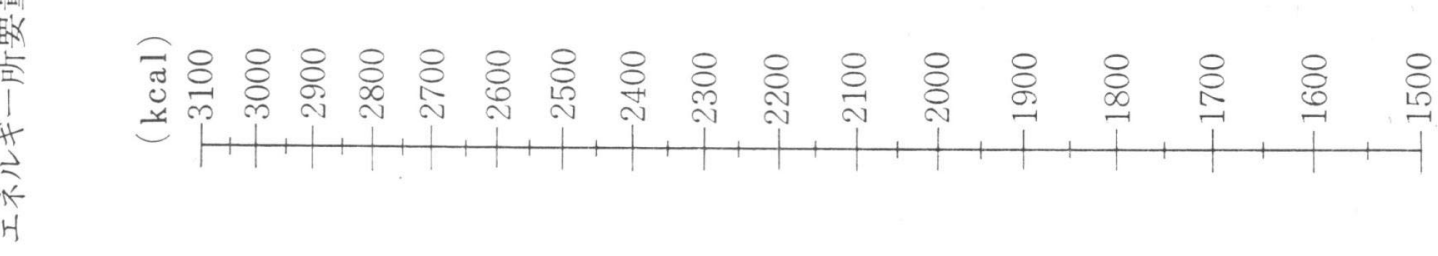

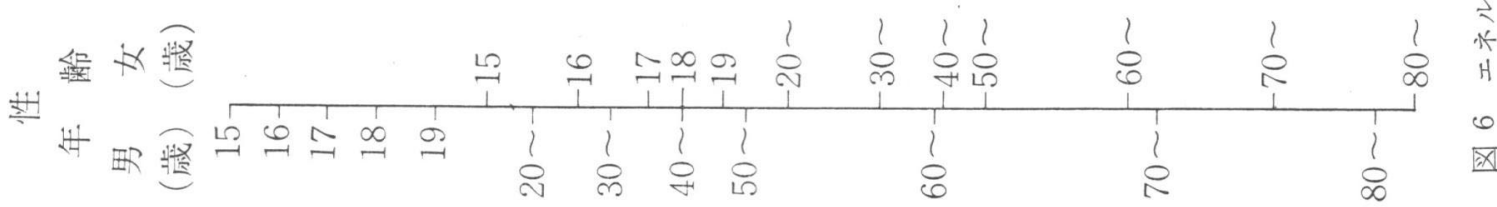
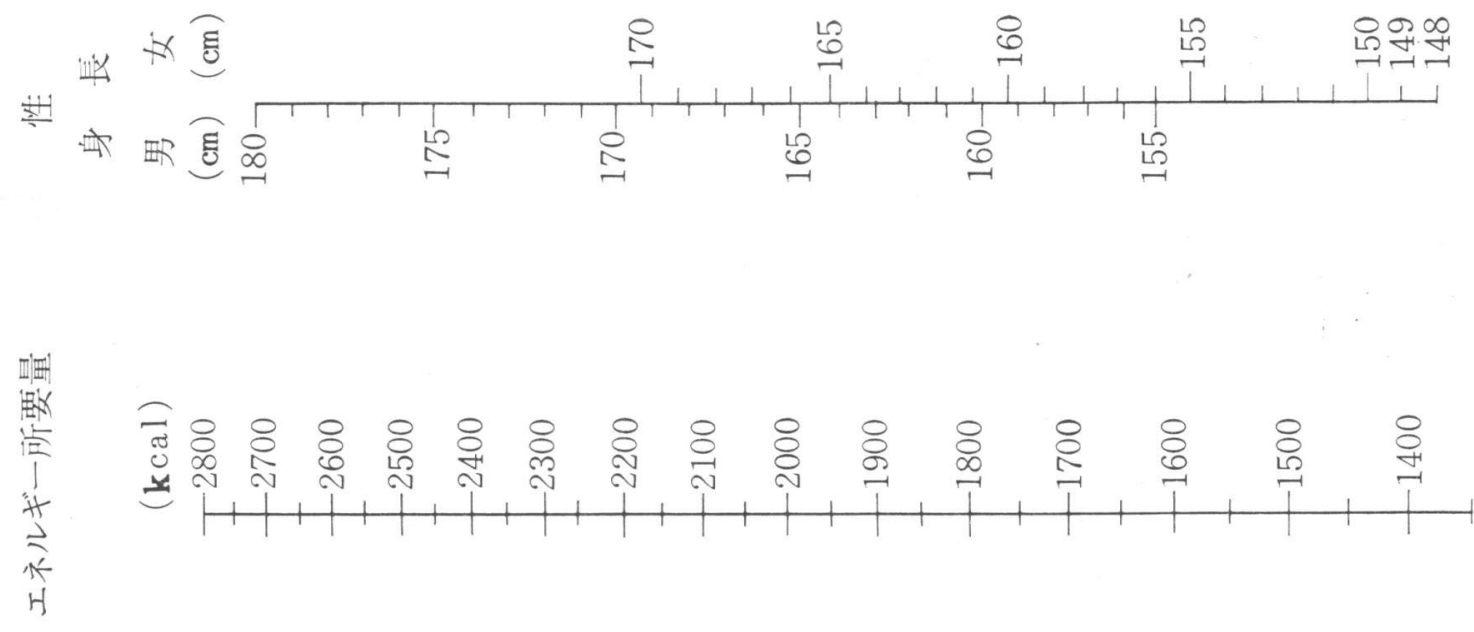

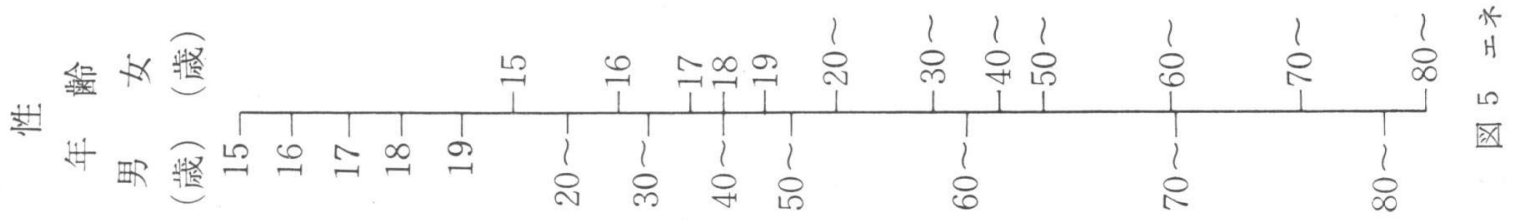


と思われる。

交献

1) 厚生省 : 日本人の栄養所要量 (1979)

2）厚生省公衆衛生局長通知：日本人の栄養所要量等の改正について (1980)

3）厚生省：日本人の栄養所要量 (1969)

4）松木 駿：ホルモンと臨床，3，625 (1955)

4）小倉金之助：計算㘠表（1940）岩波書店

（受付：昭和55年 1 月 25 日） 